\title{
A Peptide With N-Terminal Histidine and C-Terminal Isoleucine Amide (PHI) and Vasoactive Intestinal Peptide (VIP) Are Copackaged in Myenteric Neurones of the Guinea Pig Ileum
}

\author{
D. V. AGOSTON,$*^{1}$ J. FAHRENKRUG, $\dagger$ J. D. MIKKELSEN $\ddagger$ \\ AND V. P. WHITTAKER*2 \\ *Arbeitsgruppe Neurochemie, Max-Planck-Institut Für Biophysikalische Chemie, Göttingen, FR Germany \\ †Department of Clinical Chemistry, Bispebjerg Hospital \\ and $\$$ Institute of Medical Anatomy B, University of Copenhagen, Denmark
}

Received 21 December 1988

\begin{abstract}
AGOSTON, D. V., J. FAHRENKRUG, J. D. MIKKELSEN AND V. P. WHITTAKER. A peptide with N-terminal histidine and $C$-terminal isoleucine amide (PHI) and vasoactive intestinal peptide (VIP) are copackaged in myenteric neurones of the guinea pig ileum. PEPTIDES 10(3) 571-573, 1989. - When cytoplasmic extracts of the myenteric plexus of guinea pig ileum are submitted to centrifugal density gradient separation in a zonal rotor, conditions which separate storage particles containing substance $P$, somatostatin and VIP from each other, PHI copurifies with VIP. The two immunoreactivities cannot be separated by particle exclusion chromatography, which depends on size rather than density. It is concluded that the posttranslational cleavage of the propeptide or precursor to PHI and VIP occurs after packaging into these storage particles.
\end{abstract}

Copackaging Myenteric neurones PHI VIP

IT is now known that the 28 amino acid peptide, vasoactive intestinal peptide (VIP), is synthesized in the form of a propeptide or precursor which is posttranslationally modified by proteolytic cleavage to generate VIP and various other fragments, the main one of which is a 27 amino acid peptide known as PHI, standing for the peptide with $\mathrm{N}$-terminal histidine and $\mathrm{C}$-terminal isoleucine amide. VIP and PHI and/or the other propeptide cleavage products have been shown to coexist in a number of VIP-containing cells $(9,12,15,21)$; both VIP and PHI are biologically active $(22,24)$, are cosecreted (12) and have been shown to exert their actions on the same organ systems $(16,20,22-24)$. Functionally critical regions of the propeptide are conserved between rat and man (18).

The myenteric plexus-longitudinal muscle (MPLM) preparation of Paton and Zar (19) has been extensively used by the Göttingen group as a source of acetylcholine- (ACh) and neuropeptidecontaining storage vesicles. These have been isolated by high resolution density-gradient centrifugation in a zonal rotor and characterized morphologically and biochemically $(1-4,10,11$, 17). Among them is a fraction of dense-cored vesicles rich in VIP (4).

In the present work we have sought to answer the question as to whether PHI is copackaged with VIP in these storage granules of myenteric neurones by investigating whether PHI copurifies with VIP during the isolation of the VIP-containing particles. $\mathrm{Mg}^{2+}$-activated ATPase (MgATPase) and synaptophysin (SY), formerly considered to be specific synaptic vesicle markers, but now known also to be present in the neuropeptide storage vesicles of the myenteric neurones (2), have also been studied.

\section{METHOD}

\section{Subcellular Fractionation}

Density gradient separation in a zonal rotor. A modification (2) of earlier procedures $(3,4,11)$ was used. MPLM (8-10 $\mathrm{g}$ from

\footnotetext{
${ }^{1}$ Present address: Laboratory of Cell Biology, National Institute of Mental Health, Bldg. 36 Rm. 3A17, Bethesda, MD 20892.

${ }^{2}$ Requests for reprints should be addressed to V. P. Whittaker, AG Neurochemie, MPI für Biophysikalische Chemie, Postfach 2841, D-3400 Göttingen, FR Germany.
} 


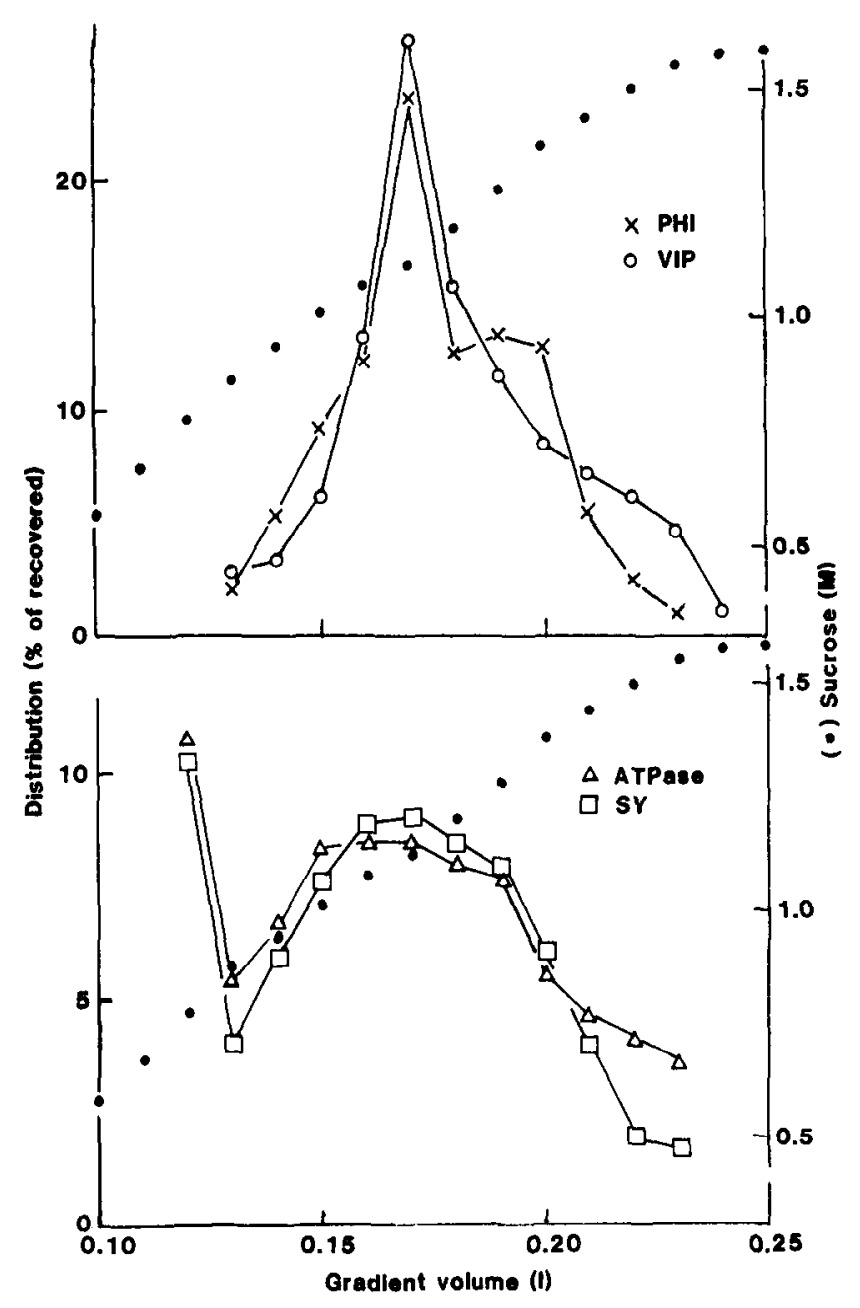

FIG. 1. Distribution of (top) VIP $(O)$ and PHI (x) and (bottom) the vesicle markers oligomycin-insensitive $\operatorname{MgATPase}(\Delta)$ and synaptophysin $(\square)$ in a sucrose density gradient after centrifugal separation of a cytoplasmic extract of MPLM in a small zonal rotor. The gradient profile (sucrose concentrations) is indicated by small dots. About 4 pmol of each neuropeptide was centrifuged into the gradient and the recovery was close to $100 \%$.

6 guinea pigs of $300-350 \mathrm{~g}$ body weight) was homogenized in

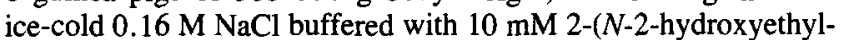
piperazine- $N^{\prime}$-yl)ethane sulphonate (Hepes), pH 6.8 and containing $1 \mathrm{mM}$ EGTA, $0.1 \mathrm{mM}$ phenylmethyl sulphonylfluoride, 100 units $\mathrm{ml}^{-1}$ of the kallikrein inhibitor aprotinin (Trasylol, Bayer), $0.01 \mathrm{mM} \mathrm{NaN}_{3}$ and $1 \mathrm{mM}$ dithiothreitol to inhibit proteases and effectively stabilize the peptides $(2,7)$. The resulting homogenate was centrifuged at $1000 \times \mathrm{g}$ for $20 \mathrm{~min}$. The precipitate was resuspended in fresh medium and recentrifuged; the combined supernatant was loaded onto a gradient formed in a zonal rotor as described (2) and centrifuged to equilibrium (6 hr at 60,000 $\mathrm{rev} \cdot \mathrm{min}^{-1}$ ). The gradient was displaced by pumping in dense sucrose and collected in $5 \mathrm{ml}$ fractions.

Separation on a step gradient. The $1000 \mathrm{~g}$ supernatants from MPLM homogenates ( $5 \mathrm{ml} /$ tube) were separated on a step gradient formed in tubes of a Beckman SW 41 rotor and consisting of layers of 1.2 and $0.9 \mathrm{M}$ sucrose ( $4 \mathrm{ml} /$ tube). After centrifuging at 41,000 rev $\cdot \min ^{-1}$ for $3 \mathrm{hr}$, the particulate fraction sedimenting between 0.9 and $1.2 \mathrm{M}$ sucrose and corresponding to most of the VIP peak

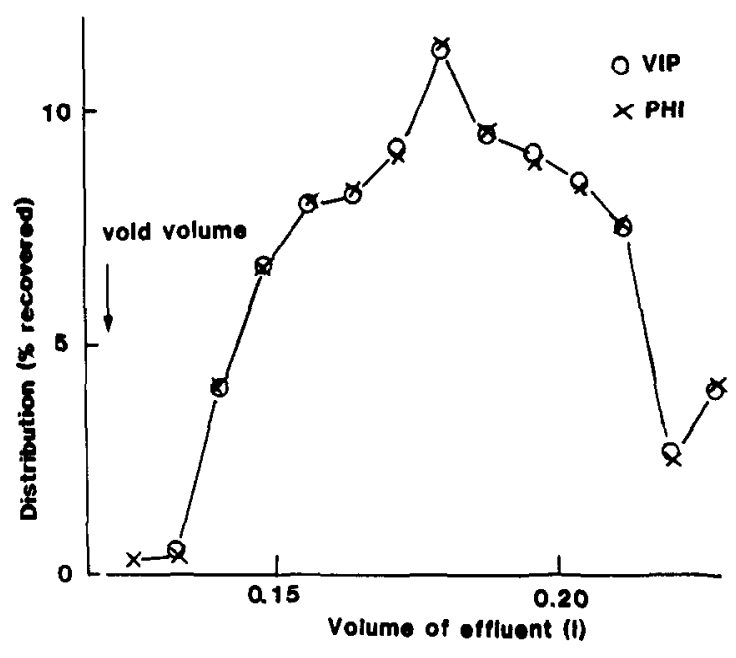

FIG. 2. Distribution of VIP $(O)$ and PHI $(x)$ in fractions obtained by particle exclusion chromatography on a $\$-1000$ column from a crude storage particle preparation previously separated in a step gradient in an SW 41 rotor. Fractions between 0.9 and $1.2 \mathrm{M}$ sucrose containing a total of 3.3 pmol of each neuropeptide were pooled and loaded onto the column. Recovery, $60 \%$.

in the zonal density gradient was collected and subjected to particle exclusion chromatography.

Particle exclusion chromatography. This was performed on a $60 \times 1 \mathrm{~cm}$ column of Sephacryl-1000 (Pharmacia) capable of resolving dense-cored vesicles from synaptic vesicles $(2,7)$. The elution buffer contained $0.32 \mathrm{M}$ sucrose, $10 \mathrm{mM}$ Hepes buffer, $\mathrm{pH}$ 6.6 (at $4^{\circ} \mathrm{C}$ ), protease inhibitors and enough $\mathrm{NaCl}$ to make it isoosmotic with the VIP peak fractions from the step density gradient. The column was conditioned before use as described (2).

Assays

Extraction. Samples of fractions from zonal density gradients or chromatographic eluates were extracted for neuropeptides and SY as previously described $(2,5,7)$.

Radioimmunoassays. VIP and PHI were assayed in extracts as previously described $(1,2,4,6,13)$. Each antiserum used was specific for its peptide $(12,14)$ and did not cross-react with the other peptide. SY was assayed by the dot-blot technique as previously described $(2,5,7)$.

Enzyme assay. MgATPase was determined in the presence of oligomycin and ouabain as previously described $(2,7)$.

\section{RESULTS}

Figure 1 shows the distribution of VIP, PHI, MgATPase and SY in a zonal density gradient after the centrifugal separation of MPLM supernatant. It will be seen that the distribution of the two peptides is almost identical. The two putative stable synaptic vesicle markers MgATPase and SY are similarly distributed but more broadly. The presence of storage particles containing other peptides [substance P, somatostatin (4), and gastrin releasing peptide, Agoston and Shaw, unpublished observations] in the region of the gradient containing 0.9 to $1.1 \mathrm{M}$ sucrose may account for this since there is no reason to suppose that these markers are confined among neuropeptide storage particles to VIP-containing vesicles. Below $0.85 \mathrm{M}$ sucrose a second peak of MgATPase and SY is discernible: this is the region of the gradient containing ACh-rich synaptic vesicles.

In Fig. 2, the effect of submitting a VIP- and PHI-containing 
fraction prepared on a step gradient to particle exclusion chromatography is shown. Again, VIP and PHI copurify with no evidence of separation.

\section{DISCUSSION}

The results presented indicate that PHI and VIP are present in a close to 1:1 molar ratio in fractions of storage vesicles previously identified as rich in VIP and dense-cored vesicles of diameter 110 $\mathrm{nm}$ (4). The failure of the two peptides to separate when their storage vesicles were fractionated on the basis of differences in density (zonal or step gradient) or size (particle exclusion chromatography) strongly suggests that they are present in the same particle. This in turn indicates that the storage vesicles were initially charged with the propeptide or precursor and that the posttranslational modification of this polypeptide by limited pro- teolysis occurs within the vesicle.

Hitherto, knowledge of the colocalization of PHI and VIP has been based on the identical distribution of the two peptides in several tissues as revealed by immunohistochemical techniques. Radioimmunoassay of tissues has indicated that they are not normally present in the 1:1 ratio expected of two peptides with a common precursor; in some tissues the concentration of VIP is higher than that of PHI, in others, the reverse is true $(8,14)$. This might be caused by different rates of catabolism of the two peptides in the various tissues. The isolation of intact storage particles containing the two peptides in a 1:1 ratio provides a new and rather direct approach to the problem of their origin and colocalization.

\section{ACKNOWLEDGEMENT}

D.V.A. was supported by Grant No. Wh 1/4-2 from the Deutsche Forschungsgemeinschaft to V.P.W.

\section{REFERENCES}

1. Agoston, D. V.; Conlon, J. M. Presence of vasoactive intestinal polypeptide-like immunoreactivity in the cholinergic electromotor system of Torpedo marmorata. J. Neurochem. 47:445-453; 1986.

2. Agoston, D. V.; Whittaker, V. P. The characterization, by size, density, osmotic fragility and immunoaffinity, of acetylcholine- and vasoactive intestinal polypeptide-containing storage particles from myenteric neurones of the guinea pig. J. Neurochem., in press; 1989.

3. Agoston, D. V.; Kosh, J. W.; Lisziewicz, J.; Whittaker, V. P. Separation of recycling and reserve synaptic vesicles from cholinergic nerve terminals of the myenteric plexus of guinea pig ileum. J. Neurochem. 44:299-305; 1985.

4. Agoston, D. V.; Ballmann, M.; Conlon, J. M.; Dowe, G. H. C.; Whittaker, V. P. Isolation of neuropeptide-containing vesicles from the guinea pig ileum. J. Neurochem. 45:398-406; 1985.

5. Agoston, D. V.; Dowe, G. H. C.; Fiedler, W.; Giompres, P. E.; Roed, I. S.; Walker, J. H.; Whittaker, V. P.; Yamaguchi, T. A kinetic study of stimulus-induced vesicle recycling in electromotor nerve terminals using labile and stable vesicle markers. J. Neurochem. 47:1584-1592; 1986

6. Agoston, D. V.; Conlon, J. M.; Whittaker, V. P. Selective depletion of the acetylcholine and vasoactive intestinal polypeptide of the guinea-pig myenteric plexus by differential mobilization of distinct transmitter pools. Exp. Brain Res. 72:535-542; 1988.

7. Agoston, D. V.; Dowe, G. H. C.; Whittaker, V. P. Isolation and characterization of secretory granules storing a vasoactive intestinal polypeptide-like peptide in Torpedo cholinergic electromotor neurons. J. Neurochem., in press; 1989.

8. Beinfeld, M. C.; Korchak, D. M.; Roth, B. L.; O'Donoghue, T. L. The distribution and chromatographic characterization of PHI (peptide histidine isoleucine amide)-27-like peptides in the rat and porcine brain. J. Neurosci. 4:2681-2688; 1984.

9. Bishop, A. E.; Polak, J. M.; Yiangou, Y.; Christotides, N. D.; Bloom, S. R. The distributions of PHI and VIP in procine gut and their co-localisation to a proportion of intrinsic ganglion cells. Peptides 5:255-259; 1984.

10. Deacon, C. F.; Agoston, D. V.; Nau, R.; Conlon, J. M. Conversion of neuropeptide $\mathrm{K}$ to neurokinin $\mathrm{A}$ and vesicular co-localization of neurokinin $A$ and substance $P$ in neurons of the guinea pig small intestine. J. Neurochem. 48:141-146; 1987.

11. Dowe, G. H. C.; Kilbinger, H.; Whittaker, V. P. Isolation of cholinergic synaptic vesicles from the myenteric plexus of guinea-pig small intestine. J. Neurochem. 35:993-1003; 1980.
12. Fahrenkrug, J. Co-existence and co-secretion of the structurally related peptides VIP and PHI. Scand. J. Clin. Lab. Invest. 47(Suppl. 186):43-50; 1987

13. Fahrenkrug, J.; Pedersen, J. H. Development and validation of a specific radioimmunoassay for PHI in plasma. Clin. Chim. Acta $143: 183-192 ; 1984$

14. Fahrenkrug, J.; Bek, T.; Lundberg, J. M.; Hökfelt, T. VIP and PHI in cat neurons: co-localization but variable content possibly due to differential processing. Regul. Pept. 12:21-34; 1985.

15. Lundberg, J. M.; Fahrenkrug, J.; Hökfelt, T.; Martling, C.-R.; Larsson, O.; Tatemoto, K.; Anggård, A. Co-existence of peptide HI (PHI) and VIP in nerves regulating blood flow and bronchial smooth muscle tone in various mammals including man. Peptides 5:593-606; 1984.

16. Miller, R. J. PIII and GRF: two members of the glucagon/secretin family. Med. Biol. 61:159-162; 1984.

17. Nau, R.; Schäfer, G.; Deacon, C. F.; Cole, T.; Agoston, D. V.; Conlon, J. M. Proteolytic inactivation of substance $P$ and neurokinin $A$ in the longitudinal muscle layer of guinea pig small intestine. J. Neurochem. 47:856-864; 1986.

18. Nishizawa, M.; Hayakawa, Y.; Zanaihara, N.; Okamoto, H. Nucleotide sequence divergence and functional constraint in VIP precursor mRNA evolution between human and rat. FEBS Lett. 183:55-59; 1985.

19. Paton, W. D. M.; Zar, M. A. The origin of acetylcholine released from guinea-pig intestine and longitudinal muscle strips. J. Physiol. (Lond.) 194:13-33; 1968.

20. Polak, J. M.; Bloom, S. R. Regulatory peptides-the distribution of two newly discovered peptides: PHI and NPY. Peptides 5(Suppl. 1):79-89; 1984

21. Raybould, H. E.; Dimaline, R. Antibodies to fragments of provasoactive intestinal peptide reveal subpopulations of vasoactive intestinal peptide containing neurons in the rat gut. Neuroscience 20:201-208; 1987.

22. Tapia-Arancibia, L.; Reichlin, S. Vasoactive intestinal peptide and PHI stimulate somatostatin release from rat cerebral cortical and diencephalic cells dispersed cell culture. Brain Res. 336:67-72; 1985.

23. Tatemoto, K. PHI-a new brain-gut peptide. Peptides 5:151-154; 1984.

24. Werner, S.; Hulting, A.-L.; Hökfelt, T.; Eneroth, P.; Tatemoto, K.; Mutt, V.; Maroder, L.; Wünch, E. Effect of the peptide PHI-27 on prolactin release in vitro. Neuroendocrinology $37: 476-478 ; 1983$. 